\title{
Family Support on Working Mother's Work-Family Conflict: Role of Communal Sharing Social Relations
}

\author{
T N E D Soeharto ${ }^{1 *}$, M W Kuncoro², S A Prahara ${ }^{3}$ \\ ${ }^{1}$ Faculty of Psychology, Universitas Mercu Buana Yogyakarta, DIY, Indonesia; \\ ${ }^{2}$ Faculty of Psychology, Universitas Mercu Buana Yogyakarta, DIY, Indonesia; \\ ${ }^{3}$ Faculty of Psychology, Universitas Mercu Buana Yogyakarta, DIY, Indonesia \\ Email : edwina@mercubuana-yogya.ac.id
}

\begin{abstract}
This study aims to determine the effect of family support on work-family conflict in mothers who work through communal sharing social relations. The formulation of the problem in this study is whether the effect of family support on work-family conflict in mothers who work through communal sharing social relations. The research was conducted with an indigenous psychological approach, carried out in the Special Region of Yogyakarta with the characteristics of the research subject is a wife who identifies herself as Javanese, has children under 12 years of age who live with her husband and work as professionals. Collecting research data using work-family conflict and family-work conflict scale, family support scale and communal sharing social relations scale given to 296 research subjects. The research data analysis used was a test measurement model at once against 4 constructs using path analysis. The conclusion of this study is that the model of the influence of family support on workfamily conflict and family-work conflict in mothers who work through communal sharing social relations is empirically tested (chi-squared value with $p>0.05$; GFI value $\geq 0.90$; AGFI value $\geq 0.90$ ). In addition, it was found that (1) family support has an effect on family conflict = work for working mothers with a total effect of 0.049 ( $\mathrm{p}<0.05$ ), but the effect is indirect through communal sharing social relations, (2) relations social communal sharing has a direct effect on work-family conflict in working mothers with a total effect of -0.263 ( $p$ $<0.05)$.
\end{abstract}

Keywords: Family support, Work-family conflict, Communal sharing.

\section{INTRODUCTION}

Labor issues become an interesting topic when it comes to the participation of men and women in the workforce. Today, there are $51 \%$ of women involved in the workforce while $82 \%$ of men. The percentage of women working as employees / employees was $36.34 \%$ and men were $41.82 \%$. The percentage of married female workers is $70.96 \%$. The level of women's participation in the workforce has an impact on improving the welfare and empowerment of women, and also shows the actualization of women [1]. This condition shows that the attitude of women in employment is getting wider even though gender inequality still exists and occurs in Indonesia. Based on the data of the [1], the percentage of women who take care of the household is $36.67 \%$ while men are only $3.99 \%$.

This is associated with a society that still adheres to a patriarchal system, men are considered to have the power, strength, by nature of men to earn a living while women are destined to be weak and take care of the household. Injustice for women occurs as a result of social constructs in a patriarchal culture [2]. The impact of this social construct is that when women work and take care of the household, there is a double burden that must be borne, there is a sense of guilt borne by women who work when they do not do household chores. Women may enter the public sector but cannot leave the domestic sector, at the same time working women are required to become wives who can manage the house, raise and 
care for children. Working women will experience problems in their dual roles, namely conflicts in terms of solving problems in the household and problems that arise in employment as working women [3].

Based on the explanation above, research on work-family conflicts needs to be carried out to examine work-family conflicts experienced by working mothers. This study needs to be carried out so that women who work do not experience the negative impact of work-family conflicts. The results of a preliminary study conducted by researchers on 40 mothers who work as professionals, it can be concluded that women who work experience high work-family conflict. Workers are supposed to experience low work-family conflict.

Work and family conflict defined by Hill et al. [4] as a form of conflict between roles, the roles that are required in work and in the family will influence each other. Greenhaus and Butell stated that fulfilling the role in work-family will make it difficult to fulfill the role of family-work [4][5]. According to Huang et al. [6] and Noor [7] work and family conflicts have two dimensions: work-family conflict and family-work conflict. The work-family conflict aspects in this study are based on aspects of workload, workplace distance, workplace conditions, relationships with leaders, relationships with coworkers [8].

Work-family conflict relates to social support that has been received. Social support in this study was obtained from family support in the form of providing information, providing assistance or materials obtained from husbands, children and extended families. This family support makes working mothers feel cared for and loved, thereby supporting the success of mothers in solving problems in the household and problems that arise in working as working women. This is supported by research by Griggs, Casper, Eby [9] that family support is negatively related to work-family conflict.

The family support received by mothers who experience work-family conflicts is related to forms of social relations. According to Fiske [10], one form of social relations is communal sharing. In communal sharing, every support given is based on the motivation to provide welfare to the family without expecting anything in return. Communal sharing social relations based on the aspects of providing inner support, protecting / guiding, helping wives, understanding their wives, being open, serving husbands and children, wives managing homes, educating children, maintaining communication, supporting husband's work, pleasing husbands [11].

This study aims to determine the effect of family support on work-family conflict on working mothers through communal sharing social relations.

\section{METHOD}

\subsection{Research design}

This research was conducted using an indigenous psychological approach, compiled based on an understanding of humans in the local context (Indigenous), so that the results of the research obtained are truly an understanding of Indonesian people so it can be applied according to the Indonesian cultural context. Not merely the adoption of theoretical concepts based on other countries' conditions

\subsection{Participants}

The research was conducted in the Special Region of Yogyakarta with the characteristics of the research subject is the wife who identifies herself as Javanese, has children under the age of 12 who live with her husband and work as professionals. The total research subjects were 296 working mothers.

\subsection{Tool}

The research data collection used a scale of family support, work-family conflict, and familywork conflict and communal sharing social relations. Items in the scale are arranged in a favorable form. The answer choices used are Strongly agree, Agree, Neutral (between agree and disagree), Disagree, and Strongly Disagree. The response of the research subject was given a score of 5 for the answer Strongly agree, a value of 4 for the answer to Agree, a value of 3 for the answer to Neutral, a value of 2 for the answer to Disagree and a value of 1 for the answer to Strongly disagree.

The total score is obtained by adding up the scores of all items. The higher the score of workfamily conflict, family-work conflict and family support, and communal sharing social relations obtained shows that work-family conflict, familywork conflict and family support, and communal sharing social relations are higher, and the lower the score. Work-family conflicts, family-work conflicts and family support, and communal sharing social 
relations that are owned show work-family conflicts, family-work conflicts and family support, and low communal sharing social relations.

Before this scale is used in research, it is tested first to find out the scale which includes validity and reliability tests. A measuring instrument is valid if the measuring instrument measures what it is actually trying to measure [12]. The validity test will show a high or low correlation coefficient value. A high correlation coefficient value will show the suitability between item functions and the function of the measuring instrument as a whole. Item selection uses a validity of $\geq 0.300$ [12], while items that have a validity coefficient of less than that number are considered excluded.

The results of testing the validity and reliability of the work-family conflict scale produce 14 valid items (the validity coefficient moves between 0.490 to 0.790 while for reliability testing using alpha reliability, it shows a reliability coefficient of 0.921 ); the family-work conflict scale resulted in 19 valid items (the validity coefficient moves between 0.361 to 0.666 while for reliability testing using alpha reliability, it shows the reliability coefficient of 0.889); the family support scale resulted in 9 valid items (The validity coefficient moves between 0.395 to 0.687 while for reliability testing using alpha reliability, it shows a reliability coefficient of 0.844 ); the social relationship scale of communal sharing resulted in 33 valid items (the validity coefficient moves between 0,420 to 0,686 while for reliability testing using alpha reliability, it shows a reliability coefficient of 0.943).

\subsection{Data Analysis}

The research data analysis used was a measurement model test of 4 variables using path analysis.

\section{RESULT}

The results of this study can be illustrated in the following figure, to see the model of the influence of family support through social relations between husbands and wives that is communal sharing on work-family conflicts in working mothers.

Based on Figure 1, it can be seen that the chisquared value is 0.916 with $\mathrm{p}=0.339$; GFI value of 0.998; AGFI value of 0.985. Based on the predetermined criteria, namely the chi-squared value with $p>0.05$; GFI value $\geq 0.90$ ); AGFI value $\geq 0.90$, the fit test results have met the criteria. Based on these results, the model is tested empirically so that the effect of family support is found through social relations between husbands and wives that are communal sharing on work-family conflicts in working mothers

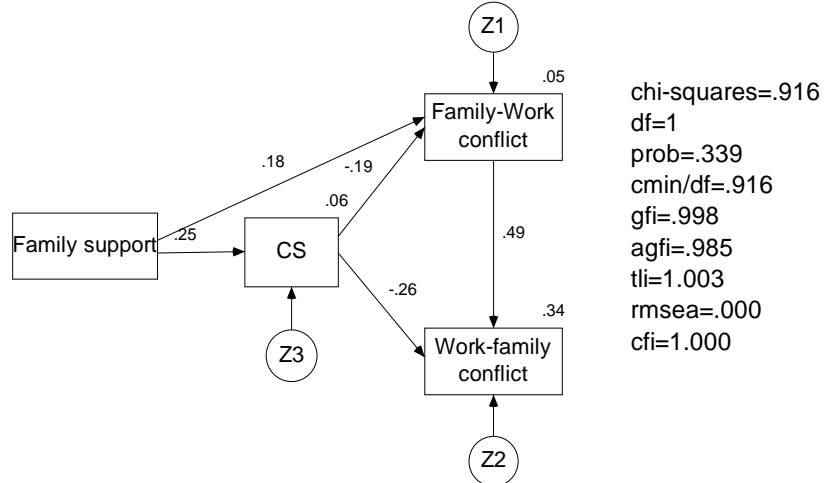

Figure 1. The model of the influence of family support through social relations between husbands and wives that is communal sharing on work-family conflicts in working mothers.

Furthermore, from the model test, it can also be seen that the direct effect, indirect effect, and total effect between variables. Family support has an influence on family-work conflicts in working mothers with a total effect of -0.049 ( $p<0.05$ ), but the effect is indirect through communal sharing social relations. Family support has a significant effect on reducing work-family conflict but the effect is indirect, namely through communal sharing, communal sharing social relations have a direct effect on workfamily conflict in working mothers with a total effect of -0.263 ( $p<0.05)$. This means that the higher the characteristics of communal sharing in the family, it will contribute to lowering the level of family-work conflict.

\subsection{Discussion}

The finding of this study is that family support has a significant effect on reducing family-work conflicts, but the effect is indirect, namely through communal sharing, family support has a role in reducing family-work conflict, when working mothers perceive the relationship between husband and wife is communal sharing. This is supported by research by [9] that family support is negatively 
related to work-family conflict. Family-work conflict is based on role theory, the roles one plays can also lead to work-family conflicts (negative values from roles at work to roles in the family). This familywork conflict is more experienced by women because according to gender theory (which is based on role theory), men and women experience different experiences about work and family problems [13].

Family support has a strong influence, especially when a child is sick so that a working mother has to leave her job [14]. This situation can add to the burden on working mothers, when there is no family to help care for the child. Even though there are babysitting services, this choice must be followed by a large amount of money, which can cause problems in family finances. Lack of family support and high costs of babysitting services can increase the likelihood of mothers leaving their jobs [15].

A working mother will feel lucky when she is able to maintain a balance between her home and work roles. Support from family can strengthen a comfortable feeling for the work they are doing, and at the same time working mothers have the opportunity to maintain their own health, can achieve success in their work. The main stresses for working mothers are less time spent on parenting and can increase guilt as a parent [16].

Previous researchers have examined the quality of relationships within the family, for example, the relationship between a working mother and her child in early development. It has been proven that when a working mother has to undertake a full-time job, it often leads to child care by nonrelatives, longer periods in school, less positive mother-child relationships, not accompanying children while learning to read. There is often a dilemma between the responsibility of caring for the child and leaving it to the caregiver [17].

Family support from husbands, children and extended families received by working mothers will reduce family-work conflicts when family support from husbands, children and extended families makes working mothers perceive the relationship between husband and wife, provided by the husband in the form of providing inner support, protecting / guiding, helping the wife, understanding the wife, being open, while the wife serves the husband and children, the wife manages the house, educates children, maintains communication, supports the husband's work, pleases the husband, based on motivation to provide welfare to the family without expecting anything in return. The perceptions of working mothers about communal sharing social relations, this family event will make working mothers feel problems with their husbands, child care, time allocation for family, household work problems, community activities, and problems with extended families will not complicate problems at work.

Through Brofenbrenner's ecological theory, it can be explained that the environment in which individuals work and the family environment interact and influence each other. There is a relationship between family, work and community [18]. Working women can feel the benefits of having several roles because there is support from their husbands, children and extended family. Working women can have positive and negative implications depending on the dynamics of family functions in the lives of women who work, whether they support or hinder them.

Another finding of this study is that social communal sharing has a direct effect on work-family conflict in working mothers, meaning that the higher the characteristics of communal sharing in the family, it will contribute to reducing the level of work-family conflict. If the working mother perceives the relationship between husband and wife as communal sharing, it will reduce work-family conflict experienced by the mother.

Working mothers perceive the relationship between husband and wife, which is given by the husband in the form of providing spiritual support, protecting/guiding, helping the wife, understanding the wife, being open, while the wife serves the husband and children, the wife manages the house, educates children, maintains communication, supporting the husband's work, pleasing the husband is based on the motivation to provide welfare to the family without expecting remuneration to make work-family conflicts experienced low.

The communal sharing relationship between husband and wife will make working mothers feel the problems of workload, workplace distance, workplace conditions, relationships with leaders, relationships with colleagues that occur at work will not complicate problems at home.

\subsection{Conclusion}

The conclusion of this study is that it is found that the influence model of family support on work- 
family conflict and family-work conflict in mothers who work through communal sharing social relations is empirically tested. In addition, it was found that (1) family support has an influence on work-family conflict among working mothers, but the effect is indirect through communal sharing social relations, (2) social communal sharing has a direct effect on work-family conflict in mothers who work.

This study has limitations, namely this research only examines family support and communal sharing social relations from the perceptions of working mothers so that suggestions for further research can involve husbands / children to examine family support and communal sharing social relations.

\section{AUTHORS' CONTRIBUTIONS}

The all author confirms responsibility for the following: study conception and design, data collection, analysis and interpretation of results, and manuscript preparation.

\section{ACKNOWLEDGMENTS}

This research was supported by Faculty of Psychology, Universitas Mercu Buana, Yogyakarta, Indonesia.

\section{REFERENCES}

[1] KPPPA, Profil perempuan Indonesia 2019. Jakarta: Kementerian Pemberdayaan Perempuan dan Perlindungan Anak, 2019.

[2] N. H. Susanto, Tantangan mewujudkan kesetaraan gender dalam budaya patriarki. Marwah 7(12) (2016) 129-130.

[3] L. Nofianti, Perempuan di sektor publik. Marwah 15(1) (2016) 51-61.

[4] E. J. Hill, C. Yang, A. J. Hawkins, M. Ferris. Across-cultural test of the work-family interface in 48 countries. J. Marriage Fam., 66(5) (2004) 1300-1316.

[5] P. Voydanoff. The effects of work demands and resources on work-to-family conflict and facilitation, J. Marriage Famiy 66 (2004) 389405.

[6] Y. H. Huang, L. B. Hammer, M. B. Neal, N. A. Perrin. The relationship between work-to-family conflict and family-to-work conflict: A longitudinal study. J. Fam. Econ. Issues 25(1) (2004) 79-100.

[7] M. N. Noor. Work-family conflict, locus of control, and women`s well-being: Tests of altenative pathways. J. Soc. Psychol. 142(5) (2002) 645-662.

[8] T. N. E. D. Soeharto, M. W. Kuncoro, Kontruksi instrumen pengukuran dukungan suami dan konflik pekerja-keluarga pada ibu yang bekerja: Berbasis pendekatan indigenous. In Prosiding Seminar Nasional dan Temu Ilmiah Ikatan Psikologi Perkembangan Indonesia (IPPI) IX “Optimalisasi Peran Keluarga untuk Meningkatkan Ketahanan Mental Menghadapi Tantangan Globalisasi," 2015.

[9] T. L. Griggs, W. J. Casper, L. T. Eby, Work, family and community support as predictors of work-family conflict: A study of low-income workers. J. Vocat. Behav. 82 (2013) 59-68.

[10] A. P. Fiske. Metarelational models: Configurations of social relationship. Eur. J. Soc. Psychol. 42 (2012) 2-18.

[11] T. N. E. D. Soeharto, M. W. Kuncoro, S. A. Prahara. Konstruksi instrumen pengukuran konflik pekerjaan keluarga pada ibu yang bekerja: Berbasis pendekatan indigenous," InSight J. Ilm. Psikol. 22(20) (2020) 103-109.

[12] S. Azwar, Reliabilitas dan validitas. Yogyakarta: Pustaka Pelajar, 2012.

[13] J. H. Greenhaus, G. N. Powell. When work and family are allies: A theory of work-family enrichment. Acad. Manag. Rev. 31(1) (2006) 72-92

[14] U. Thyen, K. Kuhlthau, J. M. Perrin. No title. Pediatrics 103(6) (1999) 1235-1242.

[15] N. M. Yantzi, M. W. Rosenberg, P. McKeever, Getting out of the house: The challenges mothers face when their children have long-term care needs. Health Soc. Care Community 15(1) (2007) 45-55,

[16] J. Poduval, M. Poduval. Working mothers: How much working, how much mothers, and where is the womanhood? Mens Sana Monogr. 7(1) (2009) 63. 
[17] K. M. Nomaguchi. Maternal employment, nonparental care, mother-child interactions, and child outcomes during preschool years. J. Marriage Fam. 68(5) (2006) 1341-1369.

[18] J. Singh, V. G. Chopra. Workplace spirituality, grit and work engagement. Asia-Pacific J. Manag. Res. Innov. 14(1-2) (2018) 50-59. DOI: $10.1177 / 2319510 \times 18811776$.

[19] B. Pocock, P. Williams, N. Skinner, Conceptualizing work, family and community: A socio-ecological systems model, taking account of power, time, space and life stage. Br. J. Ind. Relations 50(3) (2012) 391-411. 